ISSN: 1858-4837; E-ISSN: 2598-019X

Volume 15, Nomor 2 (2020),

https://jurnal.uns.ac.id/region

DOI: $10.20961 /$ region.v15i2.25300

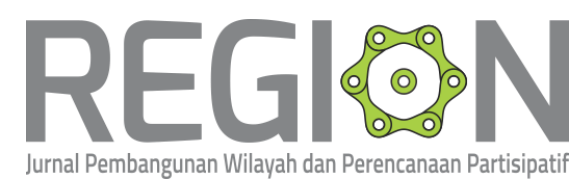

\title{
Faktor-faktor spasial yang mempengaruhi perkembangan klaster industri (Studi kasus: Industri gitar di Desa Mancasan, Desa Ngrombo dan Desa Pondok, Kabupaten Sukoharjo)
}

The spatial factors influencing industrial clusters development (Case study: The guitar industrial cluster on Mancasan Village, Ngrombo Village, and Pondok Village of Sukoharjo Regency)

\author{
N S Eminawati ${ }^{1}$, Kusumastuti $^{1}$, and Soedwiwahjono ${ }^{1}$ \\ ${ }^{1}$ Program Studi Perencanaan Wilayah dan Kota, Fakultas Teknik, Universitas Sebelas \\ Maret
}

Corresponding author's email: nurlela.seminawati@gmail.com

\begin{abstract}
Abstrak. Industri gitar yang terletak di dalam klaster Desa Mancasan, Desa Ngrombo dan Desa Pondok sudah mencapai 141 unit industri di dalam kawasan yang seluas $508 \mathrm{Ha}$, yang mengalami peningkatan 81 unit dalam kurun waktu 10 tahun. Banyak faktor yang mempengaruhi perkembangan klaster, tetapi faktor yang dapat dilihat secara langsung adalah aspek fisik atau spasialnya. Sehingga, tujuan dari penelitian ini adalah untuk mengetahui faktor-faktor spasial yang mempengaruhi perkembangan klaster industri dan pengaruh faktor spasial terhadap perkembangan klaster industri di Desa Mancasan, Desa Ngrombo, dan Desa Pondok. Analisis faktor digunakan untuk mengetahui tingkatan faktor yang dianggap paling memengaruhi menurut pengusaha di dalam klaster industri. Analisis regresi digunakan untuk mengetahui pengaruh faktor terhadap perkembangan. Faktor-faktor spasial yang mempengaruhi perkembangan klaster industri di ketiga Desa yaitu lokasi, aksesibilitas, infrastruktur, dan sarana. Hasil penelitian menunjukkan faktor utama yang paling mempengaruhi adalah lokasi klaster terhadap bahan baku maupun tenaga kerja.
\end{abstract}

Kata Kunci: Faktor; Klaster Industri; Perkembangan

Received: November 13, 2018; Accepted: December 02, 2018; Available online: July 31, 2020

Copyright $\odot$ 2020, REGION: Jurnal Pembangunan Wilayah dan Perencanaan Partisipatif 


\begin{abstract}
The guitar industry located at Mancasan Village, Ngrombo Village, and Pondok Village clusters has reached 141 industrial units within an area of 508 hectares, which increased 81 units in 10 years. Many factors influence the development of clusters, but factors which can be seen directly is physical or spatial factors. Thus, the purpose of this study was to determine the spatial factors that influence the development of industrial clusters and its influence on the development of industrial clusters in the Mancasan Village, Ngrombo Village and Pondok Village. Factor analysis was used to determine the level of factors considered to be the most influential according to employers in the industrial cluster. Regression analysis was used to determine the effect of factors on development. Spatial factors that influence the development of industrial clusters in the three villages are location, accessibility, infrastructure, and facilities. The results showed that the main factors that most affecting were the cluster location of raw materials and labor.
\end{abstract}

Keywords: Development; Factors; Industrial Clusters

\title{
1. Pendahuluan
}

Industri gitar di wilayah penelitian mulai berkembang sejak tahun 1975 sampai sekarang. Industri gitar di wilayah penelitian sudah berbentuk klaster. Klaster industri adalah kelompok industri dengan focal/core industri yang saling berhubungan secara intensif dan membentuk partnership [1]. Klaster industri dapat pula didefinisikan sebagai sekumpulan perusahaan yang berdekatan secara geografis dan saling terkait karena kesamaan [2]. Adanya keterikatan aktivitas industri yang intensif pada wilayah geografis yang berdekatan menjadikan industri dalam bentuk klaster sebagai salah satu contoh nyata dalam peningkatan partisipasi dan pemerataan proses produksi dan distribusi oleh masyarakat. Pada penelitian ini, klaster industri berada pada wilayah Desa Mancasan, Desa Ngrombo dan Desa Pondok yang bergerak di bidang kerajinan pembuatan gitar.

Dalam pengembangan banyak faktor yang dapat mempengaruhi perkembangan klaster. Faktor pendukung yang mempengaruhi perkembangan klaster dapat berupa sumberdaya manusia, alat produksi, modal, ciri khas/keunikan/inovasi produk, pasar, lokasi klaster, infrastruktur, permintaan, peran pemerintah, aksesibilitas, kemitraan [2-5]. Dalam pengembangannya, klaster industri sangat dipengaruhi oleh dukungan dari wilayahnya sendiri. Dukungan tersebut dapat dikatakan sebagai aspek spasial dari wilayah perkembangan klaster industri. Lestari [6] mengemukakan tentang faktor spasial yang berpengaruh terhadap perkembangan klaster industri yaitu perlunya sarana yang mendukung agar perkembangan klaster cepat berkembang dan mendukung kemajuan yang diharapkan. Apabila tidak ada sarana yang mendukung dan setiap industri mandiri maka perkembangan juga akan lambat. Dengan adanya sarana produksi/usaha (showroom dan koperasi) akan memudahkan pengusaha dalam menjalankan usahanya dan dapat momotong ongkos yang dikeluarkan. Berdasarkan faktor pendukung yang mempengaruhi perkembangan klaster, dapat disintesiskan bahwa bahwa faktor-faktor spasial yang mempengaruhi perkembangan klaster industri meliputi lokasi, aksesibilitas, infrastruktur, dan sarana. 
Menurut Van Dijk dan Sverrisson [7], klaster industri memiliki tiga tahap perkembangan, meliputi (a) tahap klaster pasar lokal memiliki ciri-ciri industri berdekatan dan banyak kegiatan yang bersifat komplementer, (b) tahap klaster jaringan lokal memiliki ciri-ciri industri berdekatan, banyak kegiatan serupa dan ada pembagian kerja, (c) tahap klaster inovatif memiliki ciri-ciri industri berdekatan, banyak kegiatan serupa, terdapat pembagian kerja dan adanya inovasi baru, dan terakhir (d) tahap kawasan industri memiliki ciri-ciri industri berdekatan, banyak kegiatan serupa, terdapat pembagian kerja, ada inovasi baru dan kerjasama meningkat. Hal ini sejalan dengan pendapat Marshall [8] dan Kuncoro [9], dimana klaster industri memiliki ciri sudah berkembang apabila tenaga kerja terkonsentrasi dalam satu wilayah dan berdekatannya para pemasok, memiliki spesialisasi produk, permintaan inovatif, kerjasama meningkat. Berdasarkan pendapat-pendapat para ahli diatas, dapat disimpulkan bahwa klaster industri dapat dikatakan berkembang apabila sudah memenuhi kriteria (1) Industri terkonsentrasi secara geografis, (2) Memiliki spesialisasi produk, (3) Banyak inovasi, dan (4) Kerjasama semakin kuat.

Pada penelitian ini, klaster industri gitar yang menjadi ruang lingkup wilayah merupakan klater dengan perkembangan pesat. Pada tahun 2008-2018, klaster industri mengalami perkembangan yang signifikan. Hal ini dapat dilihat dari jumlah industri dalam klaster yang mengalami pertambahan sebanyak 81 unit usaha dalam kurun waktu 10 tahun. Berkaitan dengan perkembangan klaster, Desa Mancasan, Desa Ngrombo dan Desa Pondok sebagai wilayah klaster industri berlokasi, memiliki faktor-faktor spasial yang memiliki pengaruh terhadap perkembangan klaster industri gitar tersebut.

Penelitian ini memiliki perbedaan dengan penelitian-penelitian yang sudah ada sebelumnya. Penelitian sebelumnya membahas seluruh faktor yang mempengaruhi perkembangan klaster industri secara umum, sedangkan penelitian ini memfokuskan pada pengaruh aspek spasial terhadap perkembangan klaster industri. Oleh sebab itu, penelitian ini bertujuan untuk untuk mengetahui faktor-faktor spasial yang mempengaruhi perkembangan klaster industri dan pengaruh faktor spasial terhadap perkembangan klaster industri di Desa Mancasan, Desa Ngrombo dan Desa Pondok.

\section{Metode}

Pendekatan yang digunakan pada penelitian ini ialah pendekatan deduktif dengan jenis penelitian kuantitatif. Proses pengumpulan data dilakukan dengan melakukan observasi lapangan terkait lokasi klaster, infrastruktur, sarana, aksesibilitas, persebaran industri yang dilakukan di tiga Desa yaitu Desa Mancasan, Desa Ngrombo dan Desa Pondok. Kemudian wawancara dilakukan kepada perangkat ataupun ketua paguyuban yang sudah tinggal di dalam klaster lebih dari 10 tahun dan kuesioner untuk mengetahui dan mencocokkan variabel dengan kondisi yang ada di lapangan yang disebarkan kepada 141 pengusaha yang terdapat di dalam klaster. Menggunakan data yang bersumber dari pelaku di dalam klaster dikarenakan pemerintah sangat sedikit berperan dalam pengembangan klaster ini. Data yang didapat berupa penilaian likert yang terdiri dari 5 skala penilaian yang kemudian diolah untuk analisis faktor dan regresi menggunakan SPSS. Analisis regresi yang dianggap 
mempengaruhi apabila memiliki nilai sig $<0,05$. Kerangka analisis dapat dilihat pada Gambar 1.

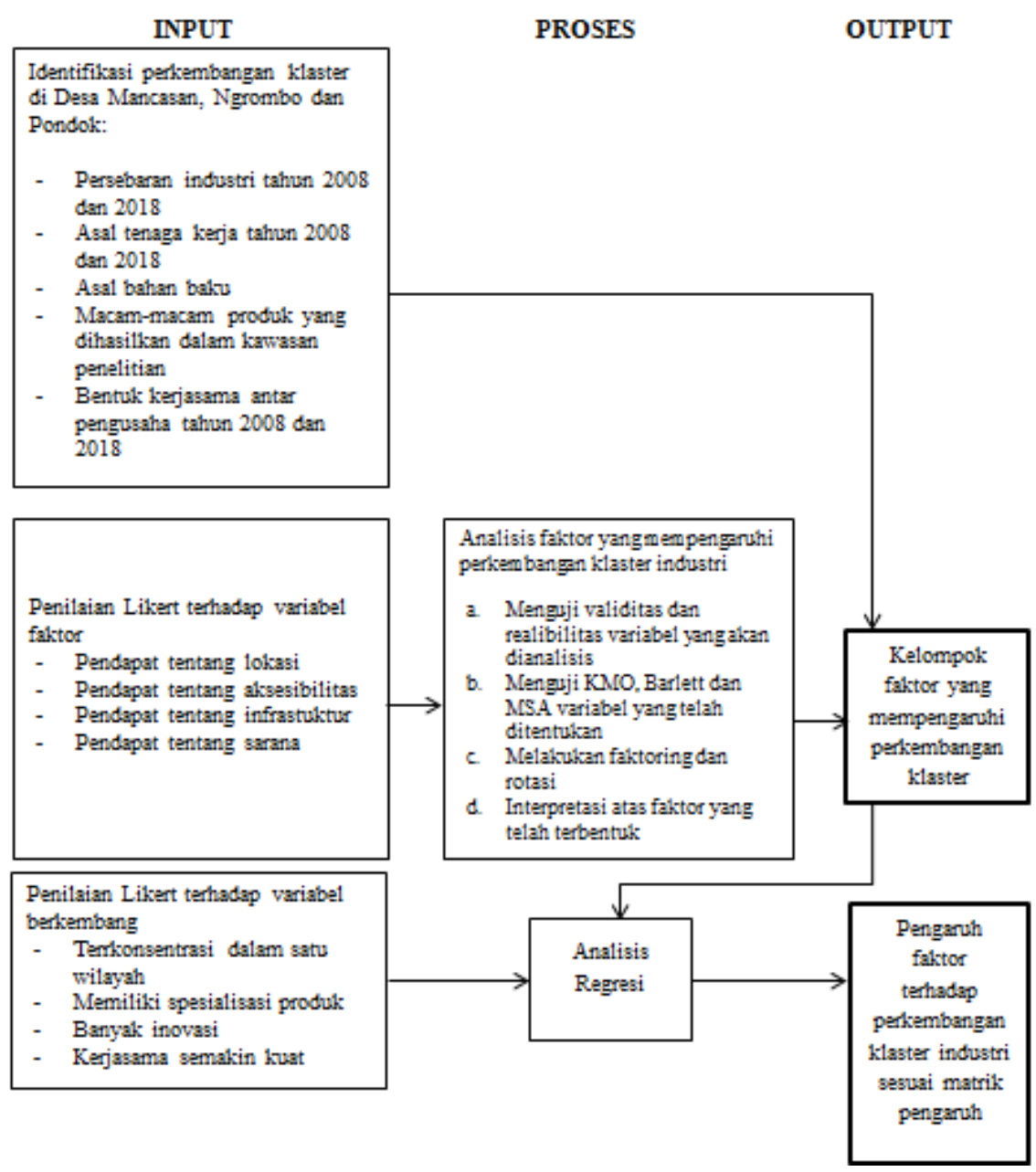

Gambar 1. Kerangka analisis.

\section{Hasil penelitian dan pembahasan}

\subsection{Faktor-faktor pendukung perkembangan klaster industri}

3.1.1 Lokasi. Kawasan penelitian yang terdiri dari Desa Mancasan, Desa Ngrombo dan Desa Pondok memiliki luas $508 \mathrm{Ha}$, dimana batas wilayah penelitian:

Sebelah utara $\quad$ : Desa Bentakan, Desa Kudu dan Desa Langenharjo

Sebelah selatan : Kabupaten Klaten dan Desa Parangjoro

Sebelah timur : Desa Telukan

Sebelah barat : : Desa Gendongan

Berdasarkan hasil kuesioner dan observasi lapangan yang dilakukan di dalam klaster diketahui bahwa lokasi klaster dikelilingi oleh sumber daya manusia yang berasal dari dalam klaster dan dari wilayah sekitar seperti Gunung Kidul, Wonogiri, Klaten, Blora, Sukoharjo dan Pacitan. Selanjutnya juga klaster industri mendapatkan bahan baku dari wilayah sekitar Received: November 13, 2018; Accepted: December 02, 2018; Available online: July 31, 2020 142 Copyright $\odot$ 2020, REGION: Jurnal Pembangunan Wilayah dan Perencanaan Partisipatif 
seperti dari Wonogiri, Kaliyoso dan Semarang. Sehingga, dapat disimpulkan bahwa untuk klaster industri sudah strategis karena lokasinya yang berada dekat dengan bahan baku dan tenaga kerja yang merupakan input utama untuk terus mendukung berkembangnya klaster industri. Peta lokasi klaster dapat dilihat pada Gambar 2.

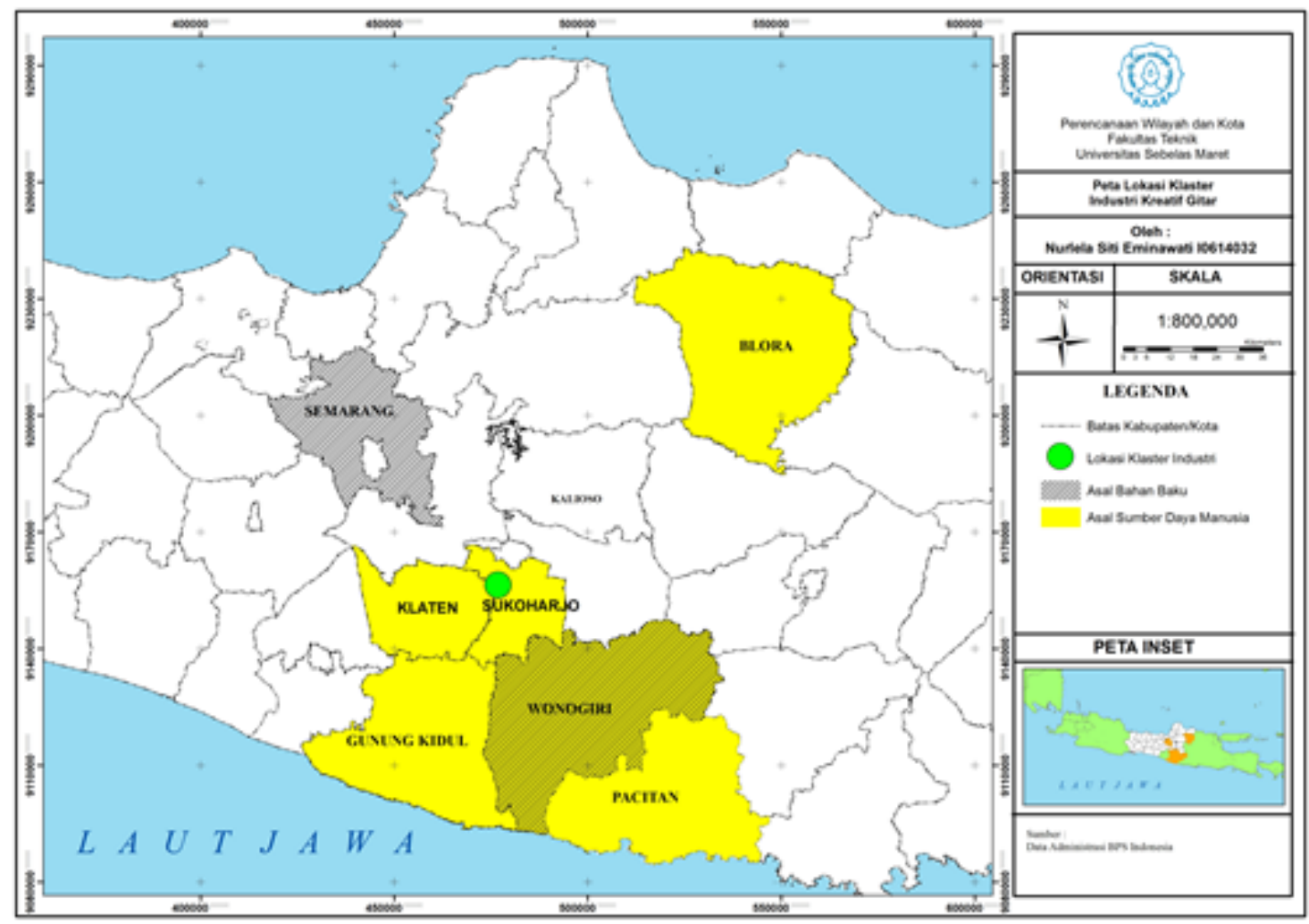

Gambar 2. Peta lokasi klaster.

3.1.2 Aksesibilitas. Dalam mengakses klaster terdapat beberapa rute yang dapat dilalui yaitu apabila dari Solo maka dapat melalui Pucangsawit - Jl. Brigjen Sudiarto - Jl. Langen Harjo - Desa Mancasan. Selanjutnya apabila dari Klaten dapat melalui JI. Wonosari, Klaten. Kemudian, apabila dari Gunung Kidul dapat melalui rute Jl. Sutowijoyo - Jl. Anggrek Mas - Jl. Satya Darma - Klaster Industri. dan apabila dari Karangayar dapat melalui rute Jl. Karanganyar - Jl. Bekonang - Jl. Ciu Karangwuni - Jl. Wonogiri Sukoharjo - Jl. Solo Sukoharjo Jl. Satya Darma - Jl. Desa Gedongan - Jl. Raya Pd. - Klaster Industri. Sehingga dapat disimpullkan bahwa untuk aksesibilitas menuju klaster industri maupun klaster industri menuju bahan baku atau tenaga kerja sudah memiliki akses yang mudah.

3.1.3 Infrastruktur. Berdasarkan hasil observasi, kondisi jalan di wilayah penelitian memiliki lebar 2-3 meter dengan kondisi jalan aspal dan baik. Kemudian, untuk listrik di dalam klaster industri yang mencukupi menurut pengusaha apabila dayanya sebesar 1300 Watt. Jalan di dalam klaster sudah menjangkau seluruh industri yang ada di dalam klaster. Sehingga dapat disimpulkan bahwa untuk infrastruktur yang berada di dalam klaster sudah cukup untuk mendukung kegiatan industri yang berada di dalam klaster. 
3.1.4 Sarana. Berdasarkan data hasil kuesioner kepada 141 responden pelaku usaha gitar menunjukkan bahwa 91\% menjawab bahwa tidak ada showroom di wilayah penelitian. Selanjutnya, hanya $9 \%$ yang menjawab tidak tahu apakah terdapat showroom atau tidak, dikarenakan showroom yang ada di dalam klaster merupakan showroom milik pribadi dan dimiliki oleh pendatang. Selanjutnya untuk koperasi, berdasarkan hasil kuesioner yang disebarkan kepada 141 responden menunjukkan bahwa 98\% menyatakan bahwa sudah tidak ada koperasi di dalam klaster, dikarenakan koperasi yang dulunya ada tidak berjalan karena pengusaha lebih memilih menjual produknya secara individu. Sehingga untuk sarana di dalam klaster sangat perlu diperhatikan dan ditambahkan sarana yang dapat digunakan bersama-sama oleh pengusaha yang berada di dalam klaster. Sehingga, dapat disimpulkan bahwa karena sistem transaksi distribusinya lebih banyak menggunakan sistem pengepul di seluruh wilayah di Indonesia, maka sarana seperti showroom tidak dianggap terlalu penting, selain itu koperasi juga tidak ada tetapi sudah ada paguyuban pengrajin gitar yang mengayomi untuk mendapatkan bantuan dan sebagai sumber pendanaan bagi pengrajin.

\subsection{Perkembangan klaster industri}

3.2.1 Industri terkonsentrasi. Perkembangan terkonsentrasinya lokasi industri dapat dilihat dari peningkatan penggunaan lahan yang digunakan sebagai industri. Luas klaster industri pada tahun 2008 sebesar 16,929 $\mathrm{Ha}$, kemudian mengalami peningkatan luas pada tahun 2018 menjadi 82,231 Ha. Selain itu jumlah industri juga meningkat dapat dilihat pada Tabel 1, Tabel 2, dan Gambar 3.

Tabel 1. Persebaran industri tahun 2008.

\begin{tabular}{ccc}
\hline No & Nama Desa & Jumlah Industri \\
\hline 1 & Desa Mancasan & 42 \\
2 & Desa Ngrombo & 17 \\
3 & Desa Pondok & 1 \\
\hline
\end{tabular}

Tabel 2. Persebaran industri tahun 2018.

\begin{tabular}{ccc}
\hline No & Nama Desa & Jumlah Industri \\
\hline 1 & Desa Mancasan & 80 \\
2 & Desa Ngrombo & 58 \\
3 & Desa Pondok & 3 \\
\hline
\end{tabular}




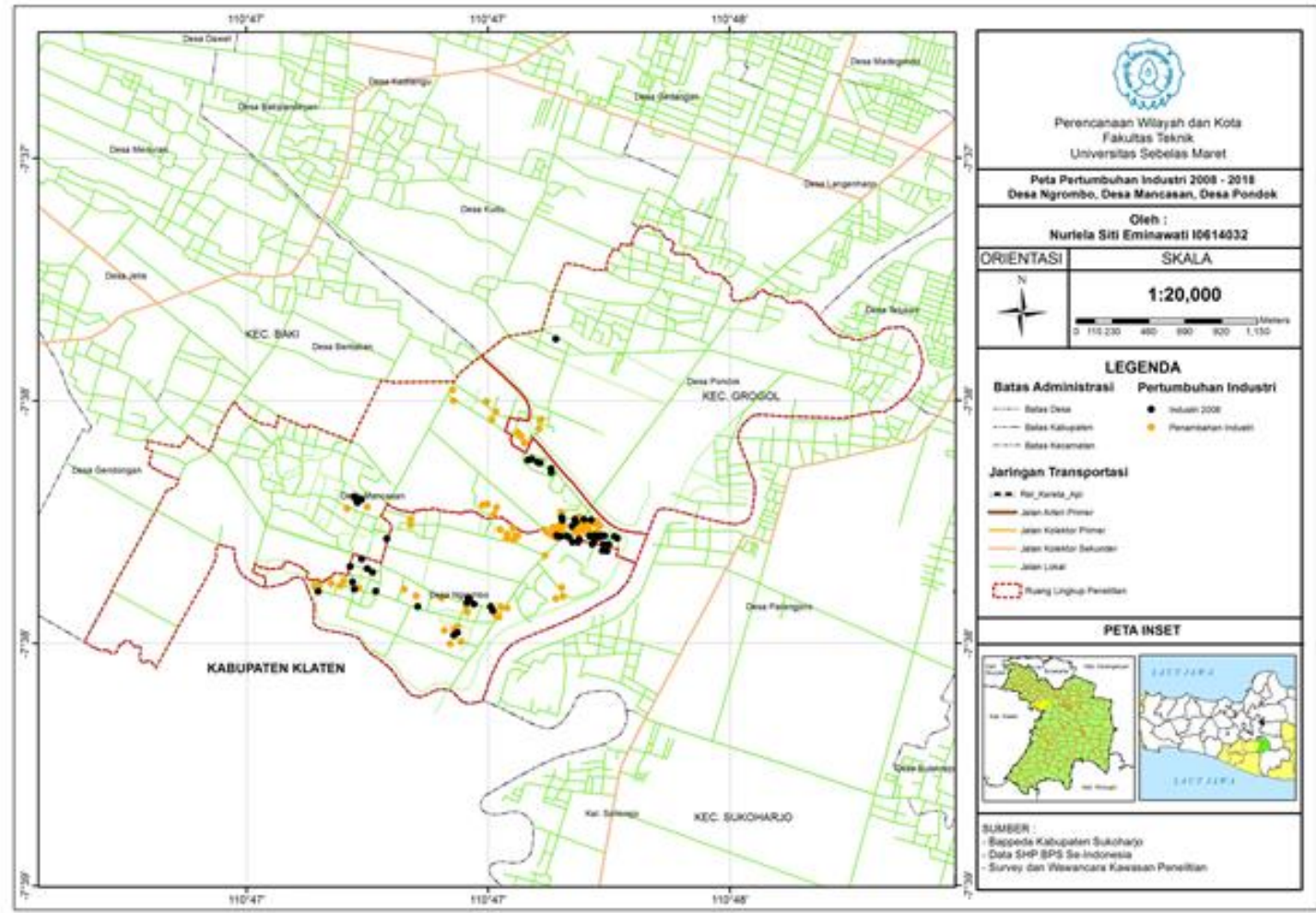

Gambar 3. Peta pertumbuhan industri 2008 dan 2018.

Sehingga dapat disimpulkan bahwa untuk klaster industri gitar yang berada di wilayah penelitian sudah sangat terkonsentrasi berkembangannya, khususnya perkembangan di Desa Mancasan dan Desa Ngrombo juga semakin meningkat dan terkumpul.

3.2.2 Kerjasama. Kerjasama di dalam klaster industri mempengaruhi pembagian ruang. Dalam proses membuat gitar di dalam klaster industri pada wilayah penelitian terdapat pembagian proses pembuatan gitar. Pembagian proses pembuatan gitar itulah yang membuat terbentuk kerjasama di dalam klaster semakin kuat. Peta pembagian proses produksi gitar dapat dilihat pada Gambar 4. 


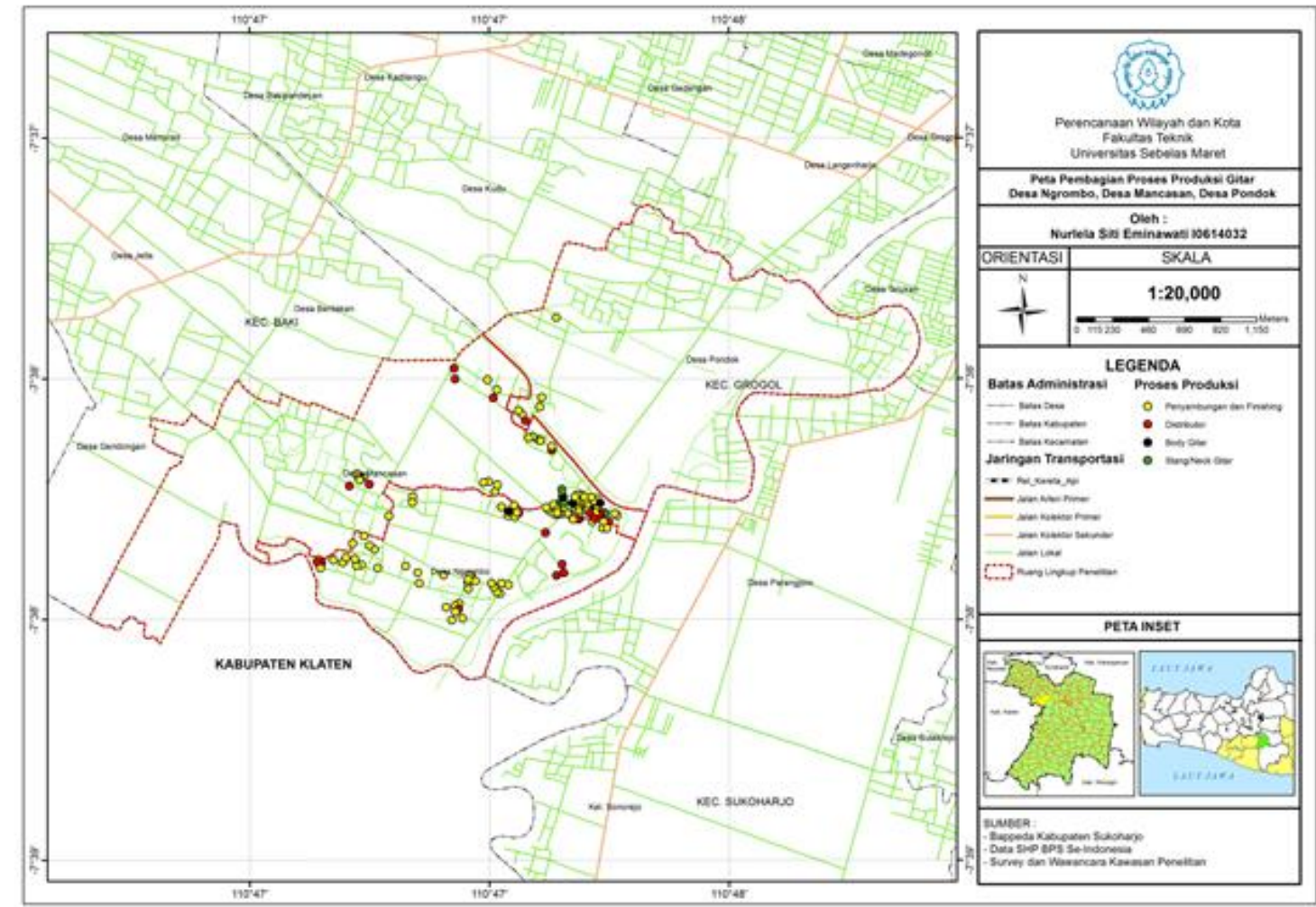

Gambar 4. Peta pembagian proses produksi gitar.

3.2.3 Spesialisasi produk. Berdasarkan hasil kuesioner dan observasi lapangan, produk yang dihasilkan oleh klaster industri ialah produk gitar. Sebanyak 141 industri yang berada di dalam klaster memproduksi gitar, sehingga dapat disimpulkan bahwa spesialisasi produk yang dihasilkan oleh klaster industri di wilayah penelitian ialah gitar.

3.2.4 Inovasi. Berdasarkan hasil wawancara dan kuesioner. Pada tahun 2008 produk gitar yang dihasilkan hanya gitar standart, kemudian dengan berkembangnya alat dan ketrampilan tenaga kerja pada tahun 2010 mulai membuat gitar listrik. Berdasarkan hal tersebut inovasi di dalam klaster dalam wilayah penelitian dapat dikatakan tidak terlalu banyak karena produknya juga merupakan produk yang permintaannya standart. Produk gitar yang dihasilkan dapat dilihat pada Gambar 5. 


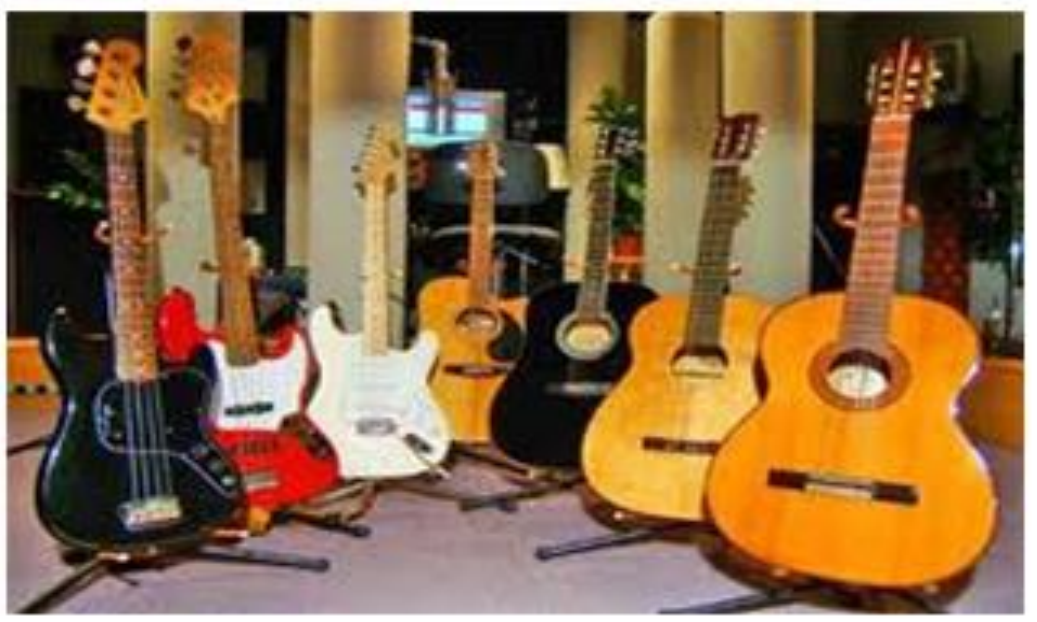

Gambar 5. Produk gitar listrik yang dihasilkan.

\subsection{Analisis faktor spasial yang mempengaruhi perkembangan klaster industri}

Dalam penelitian ini difokuskan pada faktor yang berkaitan dengan faktor spasial yang mempengaruhi perkembangan klaster industri, oleh karena itu tidak menggunakan faktorfaktor umum yang mempengaruhi perkembangan klaster industri, yang mana dari penilaian likert yang disebarkan kepada pengusaha yang berada di dalam klaster industri. Penilaian likert spasial dapat dilihat pada Tabel 3.

Tabel 3. Penilaian likert faktor spasial.

\begin{tabular}{ccccc}
\hline Skala Likert & Lokasi & Sarana & Infrastruktur & Aksesibilitas \\
\hline 1 & - & - & - & - \\
2 & 1 & 2 & 1 & 2 \\
3 & 14 & 36 & 12 & 20 \\
4 & 42 & 44 & 50 & 104 \\
5 & 84 & 59 & 78 & 15 \\
\hline
\end{tabular}

Dari data yang sudah didapat kemudian diolah dengan analisis faktor menggunakan SPSS untuk mengetahui tingkat kepentingan yang dibutuhkan oleh klaster industri untuk mendukung perkembangan klaster industri, didapatkan hasil yang dapat dibaca melalui komponen matrix pada Tabel 4.

Tabel 4. Komponen matrix.

\begin{tabular}{lcc}
\hline & \multicolumn{2}{c}{ Component } \\
\cline { 2 - 3 } & \multicolumn{2}{l}{2} \\
\hline Lokasi & .935 & .074 \\
Sarana & .042 & .856 \\
Infrastruktur & .932 & .118 \\
Aksesibilitas & .135 & .836 \\
\hline
\end{tabular}

Received: November 13, 2018; Accepted: December 02, 2018; Available online: July 31, 2020 
Berdasarkan hasil analisis tersebut didapatkan tingkatan kepentingan dari masing-masing faktor dengan melihat komponen matrix, bahwa urutan faktor sebagai berikut:

- Lokasi, faktor loading dengan nilai 0,935. Hal ini berarti lokasi dianggap merupakan faktor utama yang sangat dibutuhkan untuk mendukung perkembangan klaster

- Infrastruktur, faktor loading dengan nilai 0,932. Hal ini berarti bahwa infrastruktur dianggap masuk dalam urutan kedua faktor yang mempengaruhi perkembangan klater industri.

- Sarana, faktor loading dengan nilai 0,856. Hal ini berarti sarana dianggap masuk urutan ketiga, dimana apabila faktor tersebut terpenuhi maka perkembangan klaster akan maksimal.

- Aksesibilitas, faktor loading dengan nilai 0,836. Hal ini berarti aksesibilitas dianggap sebagai faktor yang tidak terlalu penting untuk mendukung perkembangan klaster.

\subsection{Analisis regresi pengaruh faktor spasial terhadap perkembangan klaster industri}

Dalam penelitian ini mendapatkan data terkait perkembangan klaster selain dari observasi juga melalui penilaian likert oleh pengusaha. Penilaian likert karakter klaster industri berkembang dapat dilihat pada Tabel 5. Sedangkan untuk koefisien pengaruh faktor terhadap perkembangan klaster industri dapat dilihat pada Tabel 6.

Tabel 5. Penilaian likert karakter klaster industri berkembang.

\begin{tabular}{ccccc}
\hline Skala Likert & Terkonsentrasi & Memiliki Spesialisasi & Memiliki Inovasi & Kerjasama \\
\hline 1 & - & - & - & - \\
2 & - & 2 & 2 & - \\
3 & 6 & 20 & 65 & 8 \\
4 & 50 & 56 & 62 & 103 \\
5 & 85 & 63 & 12 & 30 \\
\hline
\end{tabular}

Tabel 6. Koefisien pengaruh faktor terhadap perkembangan klaster industri.

\begin{tabular}{|c|c|c|c|c|c|c|c|}
\hline \multirow{2}{*}{ No } & \multirow{2}{*}{ Keterkaitan } & \multicolumn{2}{|c|}{$\begin{array}{c}\text { Unstandardized } \\
\text { Coefficients }\end{array}$} & \multirow{2}{*}{$\begin{array}{c}\begin{array}{c}\text { Standardized } \\
\text { Coefficients }\end{array} \\
\text { Beta }\end{array}$} & \multirow{2}{*}{$\mathrm{t}$} & \multirow{2}{*}{ Sig. } & \multirow{2}{*}{ Hasil } \\
\hline & & B & $\begin{array}{l}\text { Std. } \\
\text { Error }\end{array}$ & & & & \\
\hline \multirow[t]{2}{*}{1} & Lokasi klaster & & & & & & \\
\hline & $\begin{array}{l}\text { terhadap } \\
\text { terkonsentrasinya } \\
\text { klaster industri }\end{array}$ & 0,764 & 0,026 & 0,930 & 29,869 & 0,000 & Berpengaruh \\
\hline 2 & $\begin{array}{l}\text { Lokasi klaster } \\
\text { terhadap inovasi }\end{array}$ & 0,224 & 0,078 & 0,237 & 2,870 & 0,005 & Berpengaruh \\
\hline 3 & $\begin{array}{l}\text { Lokasi klaster } \\
\text { terhadap kuatnya } \\
\text { kerjasama }\end{array}$ & 0,121 & 0,059 & 0,172 & 2,053 & 0,042 & Berpengaruh \\
\hline 4 & $\begin{array}{l}\text { Aksesibilitas } \\
\text { terhadap } \\
\text { terkonsentrasinya }\end{array}$ & 0,142 & 0,088 & 0,136 & 1,615 & 0,109 & $\begin{array}{c}\text { Tidak } \\
\text { Berpengaruh }\end{array}$ \\
\hline
\end{tabular}




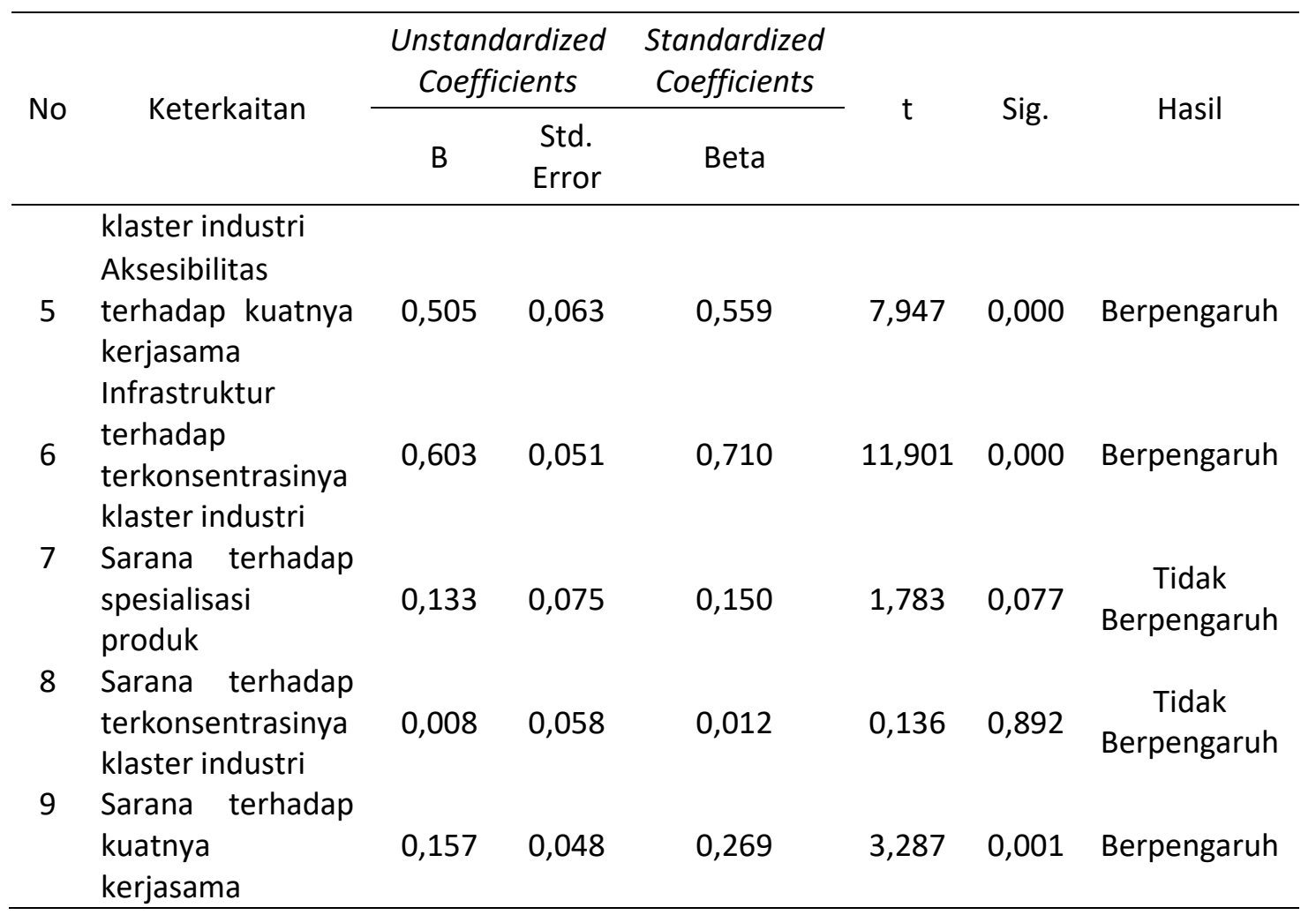

Berdasarkan analisis regresi yang telah dilakukan dengan menggunakan software SPSS seperti yang ditampilkan pada tabel di atas, didapatkan bahwa pengaruh faktor-faktor spasial terhadap perkembangan klaster industri ialah yang memiliki nilai sig $<0,05$, sehingga hasil analisis regresi faktor-faktor spasial terhadap perkembangan klaster ialah. Faktor lokasi berpengaruh terhadap perkembangan industri semakin terkonsentrasi, meningkatnya inovasi, kerjasama yang semakin kuat. Lokasi industri sendiri sebaiknya yang dapat meminimalisir biaya, seperti dekat dengan tenaga kerja, bahan baku, pasar dan teknologi [10]. Apabila dilihat berdasarkan hasil dari analisis dan hasil observasi yang ada di lapangan maka dapat dilihat bahwa dikarenakan lokasi dari klaster industri yang strategis dekat dengan bahan baku dan tenaga kerja yang berada di wilayah sekitar sehingga kerjasama yang ada juga semakin kuat dan perkembangan klaster industri gitar di dalam klaster juga semakin meningkat dan terkonsentrasi di ketiga desa, selain itu juga sumber daya yang berlokasi dari dalam klaster dan dari wilayah di sekitar klaster industri juga memicu klaster industri tetap terus dapat berinovasi karena tidak kekurangan sumber daya manusia yang terampil.

Selanjutnya, faktor infrastruktur berpengaruh terhadap perkembangan terkonsentrasinya industri. Apabila infrastrukturnya semakin baik dan mendukung maka perkembangan industri di suatu wilayah juga semakin meningkat menurut Porter [2]. Di dalam klaster industri pada wilayah penelitian sudah memiliki infrastruktur yang memadai untuk saat ini seperti jalan yang menuju setiap industri sudah dalam kondisi baik, sehingga menimpulkan 
banyak industri baru yang bermunculan juga di dalam klaster dan menyebabkan industri yang ada di dalam klaster berkumpul karena infrastrukturnya yang mendukung.

Kemudian, faktor sarana dan aksesibilitas berpengaruh terhadap perkembangan kerjasama. Apabila tersedia sarana yang memadai di dalam klaster seperti showroom yang disediakan oleh pemerintah, maka kerjasama antar pengusaha di dalam klaster juga akan meningkat, untuk saat ini berdasarkan hasil observasi lapangan belum tersedia sarana yang disediakan pemerintah, tetapi terdapat sarana yang merupakan milik individu dan sudah di anggap cukup dalam mendukung kerjasama. Faktor aksesibilitas di dalam klaster juga sudah cukup untuk mendukung kerjasama industri yang berada di dalam klaster dengan pihak-pihak terkait seperti bahan baku dan tenaga kerja karena sudah tersedia jalur yang menghubungkan antara keduanya.

\section{Kesimpulan}

Berdasarkan permasalahan yang ada di latar belakang bahwa faktor apa yang mempengaruhi perkembangan klaster industri, khusunya terkait faktor yang berkaitan dengan spasial, maka didapatkan hasil analisis faktor yang telah dilakukan dengan menggunakan software SPSS, bahwa keempat faktor yaitu lokasi, infrastruktur, sarana dan aksesibilitas mempengaruhi perkembangan klaster industri. Ke empat faktor mempengaruhi perkembangan klaster industri dengan tingkatannya masing-masing, dimana faktor yang dirasa sangat mempengaruhi perkembangan klaster industri ialah faktor lokasi, dikarenakan faktor lokasi merupakan faktor yang berkaitan dengan daya dukung wilayah dari lokasi klaster apakah sudah strategis untuk berkembangnya industri. Kemudian, faktor yang tidak menjadi hal yang terpenting untuk mendukung pengembangan klaster ialah faktor aksesibilitas.

Kemudian, berdasarkan hasil analisis regresi juga didapatkan bahwa faktor-faktor tersebut mempengaruhi perkembangan klaster dalam beberapa hal, seperti: (a) faktor lokasi mempengaruhi perkembangan klaster dalam terkonsentrasinya munculnya industri, peningkatan inovasi dan menguatnya kerjasama, (b) faktor infrastruktur mempengaruhi perkembangan klaster dalam mendukung perkembangan industri yang terkonsentrasi di dalam klaster, (c) faktor sarana mempengaruhi perkembangan klaster dalam hal peningkatan kerjasama, (d) faktor aksesibilitas juga mempengaruhi perkembangan klaster dalam meningkatnya kerjasama.

Secara keseluruhan, dapat disimpulkan bahwa untuk faktor yang benar-benar penting untuk mendukung perkembangan klaster terdiri dari faktor lokasi yang untuk saat ini sudah cukup strategis. Kemudian, untuk infrastruktur berupa jalan yang menuju industri sudah cukup, tetapi untuk listrik yang digunakan di setiap industri perlu adanya penambahan daya. Selanjutnya, untuk sarana perlu adanya perhatian agar dibuat sarana yang dapat digunakan bersama-sama oleh pengusaha agar kerjasama yang terdapat di dalam klaster dapat terkoordinasi dengan baik. Terakhir, untuk faktor aksesibilitas terhadap tenaga kerja, pasar maupun bahan baku sudah memenuhi dan cukup dikarenakan lokasi pihak-pihak terkait yang masih berada di wilayah sekitar klaster. 


\section{Referensi}

[1] Departemen Perindustrian dan Perdagangan 2000 Strategi Industri Nasional Diakses dari http://digilib.uki.ac.id:80/index.php?p=show_detail\&id=3622 pada 05-07-2020

[2] Porter M E 1990 Competitive Strategy: Techniques For Analysing Industries and Competitors (New York: The Free Press)

[3] Susanty A, Handayani N U dan Jati P A 2013 Analisis Faktor-Faktor Yang Mempengaruhi Pertumbuhan Klaster Batik Pekalongan (Studi Kasus Pada Klaster Batik Kauman, Pesindon dan Jenggot) Jurnal Teknik Industri 81 pp 1-14 DOI: 10.12777/jati.8.1.1-14

[4] Riani N Z 2011 Identifikasi Permasalahan dan Kerangka Pengembangan Klaster UMKM Sandang di Bukittinggi Sumatera Barat Jurnal IImiah IImu-IImu Sosial Budaya \& $\begin{array}{lllllll}\text { Ekonomi } & 7 & 1 & \mathrm{pp} & 51-64 & \text { Diakses }\end{array}$ http://ejournal.unp.ac.id/index.php/tingkap/article/view/11

[5] Djamhari C 2006 Faktor-faktor yang Mempengaruhi Perkembangan Sentra UKM Menjadi Klaster Dinamis (Jakarta: Infokup)

[6] Lestari E P 2010 Penguatan Ekonomi Industri Kecil dan Menengah Melalui Platform Klaster Industri Jurnal Organisasi dan Manajemen 62 pp 146-57 Diakses dari http://jurnal.ut.ac.id/index.php/JOM/article/view/289

[7] Van Dijk M P dan Sverrisson A 2003 Enterprise Cluster in Developing Countries: Mechanisms of Transition and Stagnation Journal Enterpreneurship \& Regional Development 15: 183-206 DOI: 10.1080/08985620210159239 pada 05-07-2020

[8] Marshal A 1919 Industry and Trade (London: Macmillan)

[9] Kuncoro M 2002 Analisis Spasial dan Regional (Jogjakarta: AMP YKPN)

[10] Djojodipuro M 1992 Teori Lokasi (Jakarta: Fakultas Ekonomi Universitas Indonesia) 